\title{
LANDBOUWOPVOEDING DER SURINAAMSCHE JEUGD DOOR
}

W. R. MENKMAN

Landbouwopvoeding van de Surinaamsche Jeugd. Een vraag en een antwoord. Drukkerij Eben Haëzer (P. A. May) Paramaribo - Boekhandel E. Ritter, Van Woustraat 237 Amsterdam Zuid. Prijs f 0.75

Deze brochure werd „Aangeboden aan allen, die het welmeenen met Suriname"; een schrijver wordt niet vermeld, doch de Inleiding en de Toelichting, beide gedateerd Paramaribo Juni 1938, zijn onderteekend resp. door Ds. D. Mulder en Siegfried Beck, twee leden van het Werkcomité, dat zich te Paramaribo gevormd heeft tot het uitwerken van concrete voorstellen, met betrekking tot het lenigen van den nood der stadsbevolking aldaar.

Wanneer wij voor oogen houden dat voor het Protestantsch Werkverband, voor welke organisatie het Werkcomité zijn in de brochure vervatte rapport opstelde, de nood der stadsbevolking het uitgangspunt geweest is, dan begrijpen wij dat de rapporteurs zich allereerst déze beide vragen gesteld hebben: $1^{\circ}$. Hoe kan de bevolking van Suriname voor een grooter deel dan nu het geval is, naar den landbouw geleid en in den landbouw gehouden worden, $2^{\circ}$. Hoe kan vooral de „rijpende jeugd”, dus de jeugd na het verlaten van de school, naar den landbouw worden gebracht?

Men behoeft het echter niet eens te zijn met hun conclusie, dat „het kernpunt van het groote sociale probleem in Suriname ten slotte door deze twee vragen beheerscht wordt". Hetzij men het Surinameprobleem een sociaal, dan wel een sociaal-economisch probleem wil noemen, het probleem der stadsbevolking is er slechts een onderdeel van. Volgens het laatste Surinaamsche Verslag vindt van de totale bevolking van het land, boschnegers en Indianen buiten beschouwing gelaten, ruim $56 \%$ rechtstreeks in den landbouw een bestaan; dat dit percentage niet grooter is kan misschien met meer recht als een symptoom worden beschouwd, dan als de oorzaak der kwaal. 
Boden in Suriname de mijnbouw, de boschexploitatie, het fabrieksbedrijf, de scheepvaart, enz. enz., meer arbeidsgelegenheid aan dan thans het geval is, dan zou de tegenwoordige getalsverhouding tusschen de agrarische en de stedelijke bevolkingsgroep niet abnormaal behoeven te zijn. Houdt men echter vast aan de overtuiging, dat in Suriname slechts de landbouw aan de overgroote meerderheid der bevolking een bestaan kan verschaffen, terwijl toch een te klein percentage zich aan dien bedrijfstak wijdt, dan doet zich allereerst de vraag voor hoe die landbouw tot zoodanige ontwikkeling gebracht kan worden, dat de levensstandaard van hen die er zich reeds op toeleggen wezenlijk verhoogd wordt; is die levensstandaard onvoldoende, dan biedt een kunstmatige verplaatsing van de stad naar het land weinig hoopvolle perspectieven.

Men vergete niet dat de tegenwoordige stadsbevolking in Suriname toch óók leeft, hoe sober het moge zijn; dat in een vruchtbaar geacht en in het algemeen zeer dun bevolkt tropenland zich door alle tijden heen een zóó talrijke en zóó weinig welvarende stadsbevolking gehandhaafd heeft, moet toch een economische oorzaak hebben. Waarmede geenszins gezegd wil zijn dat niet óók de traditie, óók psychische en historische factoren een rol gespeeld hebben en nog spelen.

In een tropisch landbouwgebied kan men zoowel den toestand waarnemen dat volkscultuur en loonarbeid op plantages, al dan niet gecombineerd, slechts een uiterst poover bestaan opleveren, als dien dat de plattelandsbevolking in eigen bedrijf, met of zonder bijverdiensten uit arbeid voor ondernemingen, een zekere mate van welstand geniet. Van dezen laatsten toestand heeft Nederlandsch Indië en heeft ook tropisch Amerika voorbeelden opgeleverd, zelfs Suriname. Onlangs echter verkondigde een Surinaamsch blad de stelling dat thans de bevolking uit armoede naar den landbouw gedreven wordt; misschien een naieve, maar dan toch tevens een veelzeggende uitlating.

Hebben hier te lande in vroeger dagen de landbouwkoloniën werkelijk een belangrijke rol gespeeld bij de bestrijding van het pauperisme? Het is waar, Suriname heeft enorme uitgestrektheden onontgonnen land, maar de drang om die in gebruik te nemen moet uitgaan van den bestaanden landbouw, wanneer die een hoogere trap van ontwikkeling bereikt zal hebben. Wanneer de gezeten plattelandsbevolking in Suriname ettelijke malen zoo talrijk was als nu het geval is en die plattelandsbevolking eenigermate welvarend was, dan zou het tegenwoordige aantal stads- 
bewoners niet meer onevenredig groot zijn, dan zou de stad haar natuurlijke taak kunnen vervullen in het economisch leven van het land. Misschien zijn de Aziatische kleine landbouwers in Suriname naar eigen maatstaf niet onwelvarend, maar dan deugt die maatstaf niet. Men leeft in een land waar behalve eenige voedingsmiddelen alles van buiten geimporteerd moet worden, waar de invoer, wegens den nood der openbare kas, met hooge rechten en, wegens de afgelegenheid, met hooge vrachten belast is. Een zoodanig land is relatief een duur land, waar slechts bij een hoogeren levensstandaard dan de tegenwoordige van welvaart gesproken zou kunnen worden.

Evenwel, men kan over het Surinameprobleem lang praten, maar intusschen moet er gedaan worden wat de hand te doen kan vinden en het is daarom toe te juichen dat zich opnieuw belangstelling is gaan openbaren voor het lot der opgroeiende jeugd, speciaal der opgroeiende stadsjeugd. Opnieuw, want oudere Surinamevrienden zullen zich nog herinneren het ambachtsrapport van 1912, dat eigenlijk meer een vagebondagerapport was en ook in de brochure geciteerd wordt.

De stellers van deze laatste blijken voorstanders te zijn van een landbouwkolonie met internaat, ten bate van jeugdige personen, hetzij pas van school gekomene, hetzij wat oudere, ten einde voor den zelfstandigen kleinen landbouw te worden opgeleid.

Suriname is een land van rapporten en ook een land van tegenstellingen; de tegenstellingen waarop de rapporteurs in onze brochure wijzen hebben betrekking op de Surinaamsche creolenbevolking. Er wordt veel gedaan op het gebied van het onderwijs, maar wanneer de jeugd van de school komt, is zij maar al te vaak tot lediggang gedoemd, omdat er althans voorloopig in het ambacht geen gelegenheid tot opname bestaat. De verbeterde zorg voor de volkshygiëne heeft de zuigelingensterfte beperkt en de bevolkingsaanwas bevorderd, maar de gezondheidstoestand van het opkomende geslacht wordt bedreigd door ondervoeding, als gevolg van den socialen nood.

Hierboven is reeds gezegd dat men de relatief te sterke stadsbevolking ook zien kan, niet als een oorzaak, maar als een symptoom. De samenstellers der brochure constateeren óók een trek der nakomelingschap van de Aziatische immigranten, die toch als landbouwers hun intrede in Suriname hebben gedaan, naar de stadsberoepen. Dit pleit natuurlijk niet voor gunstige toestanden in het kleine landbouwbedrijf. Men blijkt dan ook een open oog te 
hebben voor de noodzakelijkheid dat dit bedrijf zich tot een meer loonend ontwikkele. Alleen, onze rapporteurs meenen dat niet gewacht mag worden totdat in dit opzicht verbetering zal zijn ingetreden, alvorens maatregelen te nemen om de jeugd naar den landbouw te leiden. Komen wij echter zoodoende niet wederom terecht in den vicieuzen cirkel, waarin zooveel zich in Suriname beweegt?

Het ligt voor de hand dat de rapporteurs zich toch ook bezighouden met het zeer moeilijke vraagstuk hoe in den kleinen landbouw de bestaansvoorwaarden verbeterd kunnen worden, al is dit vraagstuk voor hen niet het uitgangspunt. Dat zij in deze materie nieuwe gezichtspunten openen kan niet gezegd worden en was ook niet te verwachten.

Van een creolengezin in den kleinen landbouw wordt de verklaring opgenomen dat men ruimschoots genoeg voedsel voor eigen gebruik produceerde en daarnaast met een geldinkomen van $f 1.25$ per week zou kunnen rondkomen, maar aan $f 2.50$ voldoende zou hebben, wat niet bijster duidelijk is. Van een Javaansch gezin van drie personen, op een plantage levend, maar met eigen rijstperceel, wordt gezegd dat het aan contanten ongeveer $f 1.55$ per week noodig heeft. Een Britschindisch gezin van zes personen, in de nabijheid eener plantage wonend en ook met eigen rijstland, welk gezin den indruk maakte van welvarend te zijn, zou verklaard hebben door verkoop van surplus-padi en door den loonarbeid der volwassenen op de onderneming, een geldinkomen te maken van $f$ 270.- per jaar. Deze voorbeelden uit de practijk zijn natuurlijk van veel waarde, doch er wordt aan toegevoegd dat de cijfers in kwestie niet algemeen geldend zijn en ook niet een ,zeker gemiddelde voorstellen".

De afzet der surplus-productie van de kleine landbouwers is, zooals bekend, een probleem op zich zelf, de loonarbeid op de plantages, als bron van bijverdienste, is dat eveneens. De leider van het grootste landbouwbedrijf in Suriname bepleitte in de Staten verderen aanvoer van contractarbeiders, omdat de kolonisatie de werkkrachten aan de ondernemingen onttrekt, terwijl van bestuurszijde toegegeven werd dat niet alleen de plantages geen geregelden arbeid aan vrije werknemers kunnen aanbieden, maar dat het in het algemeen ook niet mogelijk is door het uitgeven van grondjes op de plantages een stand van kleine landbouwers te kweeken, die tevens loonarbeid verrichten, zoo vaak het grootbedrijf hen noodig heeft (debatten begrooting 1939).

Het is zoo'n aantrekkelijke figuur, die zelfstandige kleine landbouwer, die op eigen grond voedselgewassen voor zich en zijn ge- 
zin verbouwt en zich door loonarbeid in den vrijen tijd een geldinkomen bovendien verschaft, maar de practijk schijnt nu eenmaal anders te zijn. En, wanneer de combinatie in kwestie voor den Aziatischen kolonist geen aantrekkelijkheid heeft, dan mag men er zeker voor den creool niet veel van verwachten. Produceeren groot en klein bedrijf dezelfde (export-)artikelen, dan vallen de oogst- en andere werkzaamheden natuurlijk voor beide samen, dan heeft de plantage voor den kolonist geen werk wanneer deze laatste beschikbaar is en wèl werk wanneer hij door eigen bedrijf in beslag genomen wordt.

Het zwaartepunt blijft derhalve de productiviteit van den kleinen landbouw op zich zelf, als een middel om ook in andere behoeften te voorzien dan die aan voedingsmiddelen voor de producenten zelf en de vraag hoe dat bedrijf tot een meer loonend gemaakt kan worden in den zin als bedoeld, is nog steeds niet opgelost. Waarbij in het oog gehouden dient te worden dat niet alleen keuze van producten, in verband met klimaat en bodemgesteldheid, verkoops- en vervoersmogelijkheden, maar ook het gehalte van het menschenmateriaal tot de belangrijke factoren behoort.

Om terug te komen op de geprojecteerde landbouwkolonie onzer brochure, laat zich natuurlijk wel berekenen hoeveel de aankoop en het weder in orde brengen eener niet meer in exploitatie zijnde plantage zou kosten, geschikt om daarop een vestiging te stichten, zooals de ontwerpers zich die denken; ook de bedrijfskosten en de vermoedelijke opbrengst van den arbeid der jeugdige kolonisten kunnen min of meer nauwkeurig begroot worden. Op zulk een plantage, of dicht in de buurt, is dan voorloopig ruimte genoeg om de ,afgestudeerden” voor zich zelf te laten beginnen, onder toezicht van de leiders der kolonie.

Begint men, zooals de rapporteurs zich voorstellen, met een dertig- of veertigtal jeugdige personen, dan kan men op een dergelijk terrein voorloopig wel voort en dan zijn er geen werkelijk aanzienlijke kapitalen noodig om het plan een kans te geven. Stelt men zich voor op den duur meerdere koloniën of kernen te stichten, dan behoeft men zich vooreerst niet ongerust te maken wat het vinden van vestigingsplaatsen betreft, want niet meer geexploiteerde of verlaten plantages zijn er helaas in Suriname genoeg. Wel echter zal dan de financieele zijde van het plan zwaar gaan wegen en door op zeer kleine schaal te blijven werken kan niet in eenigszins belangrijke mate tegemoet gekomen worden aan het euvel dat men bestrijden wil, door opleiding van de creolenjeugd tot een nuttig element der samenleving. 
Ook mag niet vergeten worden dat, wanneer de kolonisatie van Javaansche landbouwersgezinnen in Suriname uitgebreid zal worden, het gouvernement zooveel minder in de gelegenheid zal zijn andere kolonisatieplannen financieel te steunen en de neiging hebben zal zelf de hand te leggen op de geschiktste terreinen. Om nu maar niet te spreken van de enorme kapitalen welke vereischt zouden worden wanneer de zonder grooten arbeid weder in cultuur te brengen terreinen eenmaal bezet zouden zijn en met werkelijke ontginning aangevangen zou moeten worden.

Geeft dus ook het hier besproken ontwerp geen oplossing in grooten stijl van een groot Surinaamsch probleem, dan wil dat allerminst zeggen dat het niet de aandacht en de belangstelling zou verdienen van , allen, die het welmeenen met Suriname”. Opbouwend werk, met idieele bedoelingen ter hand genomen, op hoe kleine schaal dan ook, verdient aangemoedigd te worden en succes te hebben. Alleen reeds omdat zoodanig werk tot voorbeeld kan strekken en den weg kan banen tot grooter ondernemen.

Misschien moeten wij het tegenwoordige Suriname vooral zien als een kostbaar reservaat, bestemd om een deel van Java's menschen-overvloed op te nemen; dit neemt echter niet weg dat het tijd wordt ook het vraagstuk van den Surinaamschen creool of inboorling ernstig onder de oogen te zien.

Ten slotte dient nog vermeld te worden dat in de hier besproken brochure het meest op den voorgrond komen de denkbeelden van één der leden, van het reeds genoemde werkcomité, den Heer Siegfried Beck, thans door het Zendingsbestuur der Moravische Broeders tijdelijk belast met de leiding van het Kinderhuis te Saron in Suriname. Van een man die niet alleen bij herhaling groote belangstelling getoond heeft, speciaal voor den socialen kant van het Surinameprobleem, maar die ook door zijn zeer langdurige werkzaamheid in het land - en door den aard dier werkzaamheid geacht moet worden een bevoegd beoordeelaar te zijn van Surinaamsche volkstoestanden.

September 1938. 